\title{
VACCINES AGAINST COVID-19 USING NANOTECHNOLOGY: A LITERATURE REVIEW ${ }^{1}$
}

\section{VACINAS CONTRA A COVID-19 UTILIZANDO NANOTECNOLOGIA: UMA REVISÃO DA LITERATURA}

\author{
André Flores dos Santos ${ }^{2 *}$, Alessandra Soares Ayres Fraga ${ }^{2}$, \\ Patrícia Gomes $^{3}$ and Solange Binotto Fagan ${ }^{3}$
}

\begin{abstract}
In March 2020, it was declared a state of pandemic coronavirus disease (COVID-19) by the World Health Organization, which represents a public health concern. Some vaccines were created to fight the COVID-19 disease and use nanotechnology in their composition. Vaccines approved in clinical trials that are currently available for the population using nanotechnology are BNT162b2 (Pfizer, 95\% effective), and mRNA-1273 (Modern, 94, 5\% effectiveness). These vaccines use lipid nanoparticles, loaded with RNA (mRNA) to fight SARS-Cov-2. Nanotechnology can have several advantages in creating vaccines, for example, antigen protection by premature degradation to increase the immune response, control release kinetics, provide site-specific antigens, and facilitate intracellular absorption. This review article seeks to present applications of nanostructures in the production of vaccines against COVID-19 that are in the clinical testing phase and also those that have already been approved.
\end{abstract}

Keywords: Virus, pandemic, SARS-CoV-2, nanoparticles.

\section{RESUMO}

Em março de 2020, foi declarado estado de pandemia da doença coronavírus (COVID-19) pela Organização Mundial de Saúde, o que representa um problema de saúde pública. Algumas vacinas foram criadas para combater a doença COVID-19 e utilizam nanotecnologia em sua composição. As vacinas aprovadas em ensaios clínicos que estão atualmente disponíveis para a população e usam nanotecnologia são BNT162b2 (Pfizer, 95\% eficácia) e mRNA-1273 (Moderna, 94,5\% de eficácia). Essas vacinas utilizam nanopartículas lipídicas, carregadas com RNA (mRNA) para combater a SARS-Cov-2. A nanotecnologia pode apresentar várias vantagens na criação de vacinas, por exemplo, proteção de antígeno por degradação prematura para aumentar a resposta imune, controlar a cinética de liberação, fornecer antígenos especificos do local e facilitar a absorção intracelular. Este artigo de revisão tem como objetivo apresentar aplicações de nanoestruturas na produção de vacinas contra COVID-19 que estão em fase de testes clínicos e vacinas já aprovadas.

Palavras-chave: Virus, pandemia, SARS-CoV-2, nanoparticulas.

1 Study performed at Nanosciences Postgraduate Program - Fransciscan University (UFN).

2 PhD Students of the Nanosciences Postgraduate Program - Fransciscan University (UFN). E-mail: andre.santos@, ufn. edu.br, alessandrafraga@unifra.edu.br.

3 Contributors. Professors of the Nanosciences Postgraduate Program - Franciscan University (UFN). E-mail: sfagan@ ufn.edu.br, patriciagomes@ufn.edu.br.

*Corresponding author: Universidade Franciscana, Rua dos Andradas, 1614, Centro, Santa Maria - Rio Grande do Sul, 97010-030, Brazil. Email address: andre.santos@ufn. edu.br. Acknowledgments to Coordenação de Aperfeiçoamento de Pessoal de Nível Superior (CAPES-Brazil) for funding the research. 


\section{INTRODUCTION}

In December 2019, coronavirus disease (COVID-19) was first recognized as a disease caused by severe acute respiratory syndrome (SARS-CoV-2) with the main site of infection in Wuhan, Hubei Province, China (ZHU et al., 2020). The virus that caused the outbreak was recognized as 'coronavirus'. However, this is the name of the virus family to which it belongs (Coronaviridae). Within this family, there are other variations of the virus, such as Severe Acute Respiratory Syndrome Coronavirus (Sars-CoV) and Middle East Respiratory Syndrome (Mers-CoV), which are known to scientists. To differentiate this new variation that emerged recently, at first, many experts referred to it as the 'new coronavirus'. Until it had its official name defined: Sars-CoV-2, which means 'severe acute respiratory syndrome - coronavirus 2'. The World Health Organization (WHO), defined that the respiratory disease caused by the new coronavirus infection should be called Covid-19. The name of the disease results from the words 'corona', 'virus', and 'disease', indicating the year in which it appeared (2019). It was initially believed that the disease was confined to China alone, but it quickly spread around the world and was declared a pandemic by the World Health Organization in March 2020. Currently with 247,219,391 confirmed cases of COVID-19, and 5,016,369 people have died worldwide from the disease (as of November 2021) (DONG et al., 2020; HOPKINS, 2021).

There have been several attempts to find an effective treatment against COVID-19 since then, however, most results have been disappointing and others controversial. Even unveiling some mechanisms involving COVID-19, the scenario is still quite challenging (PACHECO et al., 2020). As shown during the current COVID-19 pandemic, reliable and efficient vaccine delivery systems are urgently needed for the development of vaccines against COVID-19 as well as other emerging pathogens (PARK et al., 2021). Developing a vaccine takes time, as vaccines must be not only protective but also safe. Unlike other drugs that are administered to sick patients, vaccines are administered to healthy patients and require very high safety margins (SINGH; MEHTA, 2016). Therefore, the development of a safe and effective vaccine that can prevent SARS-CoV-2 infection and transmission has quickly become a priority (BROUWER et al., 2021).

According to the human body's immune response mechanism, a vaccine considered effective must contain antigens, immunological enhancers (adjuvants), and/or target-specific delivery systems, for example using carrier nanostructures (PASHINE et al., 2005). Adjuvants are pharmacological or immunological agents used to activate the innate immune system, allowing it to respond quickly to infections and boosting adaptive immune responses that are specific to viral infections (MAO et al., 2021). However, there are few licensed adjuvants for human vaccines (SHI et al., 2019), making the 
development of vaccines against viruses difficult. In recent years, nanoparticles have attracted attention and were developed as adjuvants against several viruses (MAO et al., 2021).

The structure of the nanoparticle can be controlled to become a depot for loading antigens, preventing degradation and prolonging exposure to the antigen. Different sizes and morphology of nanoparticles allow them to induce different immune responses and deliver antigens to target or specific sites (MAO et al., 2021).

Vaccines can be prophylactic or therapeutic, with some possible classifications: live attenuated vaccines, that is, where microorganisms remain alive (pathogenic microbe), but altered in a way that can cause an immune response and not lead to infection (LASRADO et al., 2021); inactivated vaccines, which are those where the microorganisms are dead, but deceive the immune system with the dead infectious agent or part of it, triggering a protection process (HOFFMANN et al., 2021); subunit or protein vaccines (purified antigens) are made up of protein fragments or parts of coronavirus proteins that mimic its structure (FERRAZ, 2021; LARSEN et al., 2021), or toxoid vaccines, that is, made with modified toxins, unable to cause disease. Toxoids usually generate a weak immunization, requiring some reinforcement after a few years, for example, the tetanus vaccine (TICHA et al., 2021).

Nucleic acid-based vaccines, i.e., DNA (as plasmids) and RNA (as messenger RNA -mRNA) vaccines, pave the way for safe and effective biological products to mimic inoculation with live organism-based vaccines, particularly for stimulation of immune-mediated cells (CHANDLER et al., 2020; JAHANAFROOZ et al., 2019). Although nucleic acid-based vaccines demonstrate significant advantages over traditional vaccines in terms of safety, efficacy, induction of B and $\mathrm{T}$ cell responses, and specificity, it is important to mention that mRNA vaccines have advantages when compared to vaccines based on other types of nucleic acids. Furthermore, DNA vaccines present a potential risk of integration into the host genome, which can result in insertional mutagenesis (JAHANAFROOZ et al., 2019). In contrast, mRNA vaccines are only targeted for cytoplasmic delivery, bypassing the risk of genomic integration (PARDI et al., 2018; JAHANAFROOZ et al., 2019).

The mRNA vaccines have emerged in recent years as an option in cancer treatment (HOECKE et al., 2021). In combination with nanoparticle-based formulations that increase transfection efficiency (insertion of nucleic acids into cells) and facilitate targeting of the lymphatic system, nucleosidemodified mRNA provides effective delivery of cytokines, costimulatory receptors, or therapeutic antibodies (BECK et al., 2021). 
Figure 1 - Structural elements of mRNA therapy.

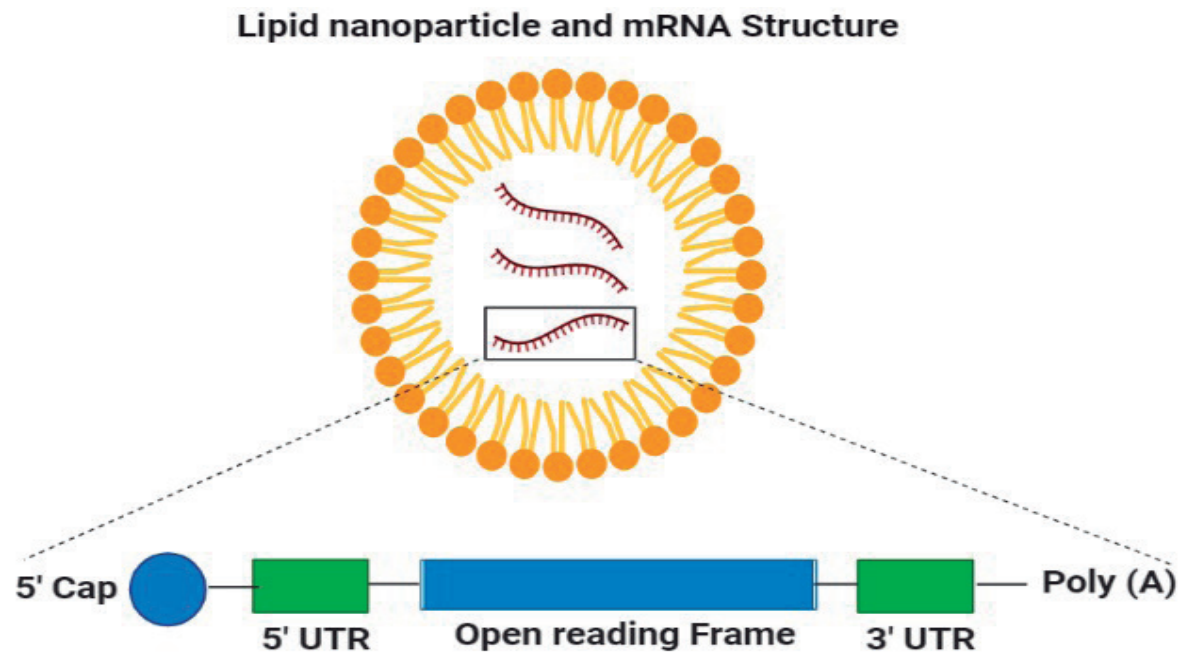

Source: Author construction (Created in Biorender.com)

Figure 1 shows structural elements of mRNA therapy. At the top is the schematic structure of the lipid-based mRNA nanoparticle (LNP - Lipid Nanoparticles) and at the bottom the structure of the synthetic mRNA, comprising a cap 5', 5' and 3' UTRs (UTR - Untranslated Region), the Open Reading Frame (ORF) and a 'poly (A)' tail. The adjustable structural elements that influence mRNA translation are the 5' cap, 3' and 5' UTRs, and the codon used in the ORF, in the case of SARS-CoV-2 the ORF is a nucleoside encoded by spike protein (S). Innate immune activation is related to nucleoside modification, and stability is related to the 5'cap and 'Poly(a)' tail (BECK et al., 2021).

Therapeutic strategies based on nanotechnology represent a promising approach to overcome the limitations found in prevention, diagnosis, and therapies against COVID-19 (WEISS et al., 2020). In therapy with COVID-19, nanotechnology has wide application and can act at different stages of the disease, with the potential to inhibit virus-cell interaction, membrane fusion, cell internalization, transcription, translation, and viral replication, in addition to activating intracellular mechanisms that cause virus irreversible damage (MAINARDES; DIEDRICH, 2020).

The mRNA vaccines are largely coupled with immunological adjuvant and various delivery strategies that can increase antigen reactivity. The delivery strategies most used by researchers in recent years are mRNA vaccines based on lipid transporters (LNP), polymers, peptides, pseudovirus particles (VLP - Virus-like Particle), cationic nanoemulsions, and newly developed dendritic cells to induce adaptive immunity (WANG et al., 2021).

This review aims to discuss the presence of nanotechnology in vaccine production, the challenges and opportunities of the manufacturing processes, and the delivery platforms that are needed for global vaccination. The advantages of using nanotechnology over other technologies used and perspectives regarding mRNA vaccines against viruses and other diseases. 


\section{METHODOLOGY}

This study is defined as exploratory of the type of integrative review in the literature. The search was based on Boolean descriptors or operators, using the following words (English): 'SARS-CoV-2 AND vaccines AND nano*', (*Main descriptor), among others. The research took place between March and July 2021 in electronic databases: Scopus and PUBMED (US National Library of Medicine).

Some inclusion criteria were used to select the articles, such as complete articles and available in full text, with a publication date close to the current date, not being a review article, and being articles with title, abstract, and/or keywords similar to the context of the research.

After searching the chosen databases, titles and abstracts were evaluated and articles that met the prerequisites defined in this study were selected for a full reading. The following characteristics of the publications were recorded: Year of publication, name(s) of the author(s), type of biological application of nanostructures in the creation of vaccines against COVID-19, advantages of using nanotechnology in the creation of vaccines against COVID -19 .

Figure 2 - Flowchart with the article selection strategy

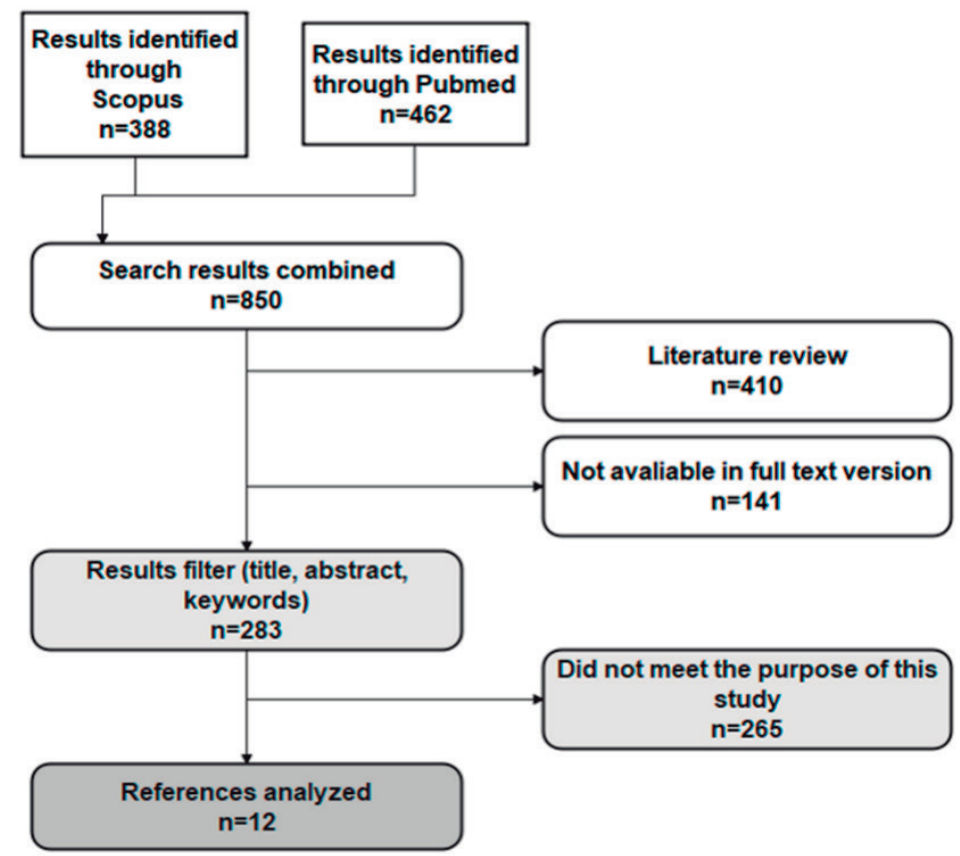

Source: Author construction.

The search in the chosen databases resulted in the collection of 850 articles, of which 12 met the criteria and were selected for inclusion in the study. Figure 2 shows the flowchart with the strategy for selecting the articles included. The publications that made up this study were published between 2020 to 2021. 


\section{RESULTS AND DISCUSSIONS}

This study presents current research related to the use of nanotechnology applied in vaccines against COVID-19. The chosen references show different types of nanoparticles used in the development of the vaccine, for example, lipid nanoparticles (LNPs) and proteins. The technologies used in vaccines with nanoparticles: mRNA, VLP, recombinant protein nanoparticles. Details are shown in Table 1.

Table 1 - Publications that made up the study.

\begin{tabular}{|c|c|c|c|}
\hline Year & Authors & Nanoparticles & Type of vaccine \\
\hline 2020 & ZHANG et al. & Lipid nanoparticles & mRNA \\
\hline 2021 & SAHIN et al. & Lipid nanoparticles & mRNA \\
\hline 2021 & RAUCH et al. & Lipid nanoparticles & mRNA \\
\hline 2021 & JIANG et al. & Protein & Recombinant protein nanoparticles \\
\hline 2021 & WANG et al. & Lipid nanoparticles & mRNA \\
\hline 2021 & TAN et al. & Protein & VLP (Virus-like particle) \\
\hline 2021 & NAG et al. & Lipid nanoparticles & mRNA \\
\hline 2021 & HUANG et al. & Lipid nanoparticles /Liposomes (LPX) & mRNA \\
\hline 2021 & CHIBA et al. & MS2 Protein & VLP (Virus-like particle) \\
\hline 2021 & KARPENKO et al. & Lipid nanoparticles & mRNA \\
\hline 2021 & TEIJARO e FERBER & Lipid nanoparticles & mRNA \\
\hline 2021 & TSIAMBAS et al. & Lipid nanoparticles & mRNA \\
\hline
\end{tabular}

Table 1 Source: Author construction.

In an approach to messenger RNA-based vaccines against coronavirus disease, caused by the SARS-CoV-2 pandemic, according to Zhang et al. (2020), describe the creation of a vaccine (ARCoV) of mRNA encapsulated by lipid nanoparticles (mRNA-LNP), which encodes the receptor-binding domain (RBD) of SARS-CoV-2 as a target antigen. According to the author, preclinical studies have shown that mRNA-based vaccines induce potent immune responses against several pathogens in animals, with an acceptable safety profile, and have a highly scalable production capacity in a short period, which makes them attractive to fight pandemics. In this study we evaluated the immunogenicity and protection of the mRNA vaccine against SARS-CoV-2 in animal models, supporting clinical development in humans. The average size of the nanoparticles was $85.85 \mathrm{~nm}$ with more than $96 \%$ encapsulation. A single or two-dose $\mathrm{ARCoV}$ immunization elicited robust antibody and T-cell responses in mice and monkeys against multiple epidemic strains of SARS-CoV-2. The RBD antigen can induce fewer non-neutralizing antibodies, reducing the risk of increased Antibody-Dependent Enhancement (ADE) infection, the potential of SARS-CoV-2 infection.

According to Sahin et al. (2021), BNT162b2 is an mRNA vaccine, with modified nucleoside formulated in lipid nanoparticles, which encodes the spike glycoprotein of SARS-CoV-2. It was created by Pfizer and was 95\% effective in preventing COVID-19. The vaccine-induced strong antibody responses when compared to individuals who had COVID-19. The serum produced by the 
vaccine also neutralized 22 pseudoviruses containing the glycoprotein $\mathrm{S}$ from different variants of SARS-CoV-2. Some advantages of these types of vaccines are molecularly well defined and efficiently synthesized from DNA models by in vitro transcription, the production of mRNA and the formulation of lipid nanoparticles are fast and highly scalable, which makes this technology great for a scenario of need for rapid development, for example, a pandemic.

In the study by Rauch et al. (2021), a vaccine called CVnCoV with mRNA technology encapsulated by lipid nanoparticles, which encodes the spike protein (S) of SARS-CoV-2 stabilized in fulllength pre-fusion was developed. The spike protein (S) is the main antigenic target of SARS-CoV-2 and interacts with human angiotensin 2 (ACE2-Angiotensin-Converting Enzyme) which allows the cellular entry of the virus (HOFFMANN et al., 2020). Immunization with CVnCoV vaccine-induced humoral responses with high virus-neutralizing antibody responses and potent $\mathrm{T}$ cell effects. Tests were performed in animals demonstrating the absence of viral replication in the lungs and no disease problems were evidenced by the application of the vaccine, which demonstrates that is an excellent and safe candidate against SARS-CoV-2 (RAUCH et al., 2021).

Jiang et al. (2021) developed a vaccine against SARS-CoV-2 called NVX-CoV2373 from the full-length spike protein, stable in the pre-fusion conformation. The nanoparticles have a size of 27.2 $\mathrm{nm}$, are thermostable (resistant to temperature), and bind with high affinity to the ACE2 receptor. The vaccine was tested in mice with a Matrix-M adjuvant based on saponin (plant glycoside) and elicited a high-grade anti-S IgG that blocks binding to the ACE2 receptor, neutralizes the virus, and protects against SARS-CoV-2, no association of the vaccine with increased respiratory disease.

Called SW0123 a sequence-modified mRNA vaccine that encodes the Spike protein of SARS-CoV-2 and is encapsulated in lipopolyplex structured core nanoparticles (LPP-Lipopolyplex Nanoparticles). According to Wang et al. (2021), the vaccine is easy to produce on a large scale, its absorption is facilitated by the nanoparticle structured in a core-shell, it demonstrates high colloidal stability and a desirable biodistribution pattern with low targeting effect to the liver in intramuscular administration. Evaluations in animals of the vaccine demonstrated good T-cell responses, with high levels of antibodies capable of neutralizing wild-type SARS-CoV-2 and including the D614G variant. The author reports on some concerns in mRNA vaccines, regarding the unfavorable biodistribution pattern due to their unique size and composition, and problems related to production, stability, and necessary storage conditions (low temperatures). Through Transmission Electron Microscopy (TEM), the mean core size of the nanoparticles was identified, which was between $45 \mathrm{~nm}$ in diameter, through the procedure based on microfluidics, a lipid envelope layer was surrounded to the dense core, adding the nanoparticle size at $200 \mathrm{~nm}$ in diameter (WANG et al., 2021).

Tan et al. (2021), describe a protein nanoparticle vaccine against SARS-CoV-2. The vaccine is based on the receptor-binding domain of the spike (S) glycoprotein of the coronavirus (RBD), on a synthetic virus-like particle. In tests performed with rats and pigs, low doses of the vaccine induced a 
strong neutralizing antibody response, considered superior to convalescent human serum. According to the author, recent studies indicate that the RBD of SARS-CoV-2 induces neutralizing antibodies. Therefore, in this research, the immunogenicity of RBD, which was conjugated to a VLP, was verified. The VLP demonstrated that the protein antigen further increases immunogenicity, facilitating antigen drainage into lymph nodes, increasing uptake by cells that present the antigen, and cross-linking of the B cell receptor. The VLP platform is based on an aldolase (enzyme) engineered from thermophilic bacteria, spontaneously assembles into a hollow 36 -nanometer dodecahedral cage with 60 subunits. The vaccine is highly immunogenic in animals, inducing robust SARS-CoV-2 neutralizing antibody responses.

In the study by Nag et al. (2021) a vaccine called GBPD060, which uses mRNA-LNP technology specific for the D614G genotype of the SARS-CoV-2 virus, was developed and is being tested in animals. According to the author, the vaccine generated specific antibodies against SARS-CoV-2 in rats. It is encapsulated in lipid nanoparticles (LNP) with a size between 60 and $140 \mathrm{~nm}$, based on mRNA encoding the 'spike' (S) glycoprotein of SARS-CoV-2 with unmodified nucleoside (unmodified molecule), stabilized in its conformation of pre-fusion (before deformation). The coronavirus family has genetic review mechanisms, some SARS-CoV-2 sequence variations are comparatively low. However, natural selection can adopt rare but convenient mutations. Since the beginning of the pandemic outbreak in China, SARS-CoV-2 has undergone numerous mutations, one of them the alteration in the amino acid D614G in the ' $S$ ' protein of the Wuhan reference strain, caused by the substitution of a nucleotide (NAG et al., 2021). Currently, D614G is considered the most prevalent circulating isotope of SARS-CoV-2 worldwide (KORBER et al., 2020). According to Nag et al. (2021), bioinformatics analyzes were performed to discover the available protein (S) sequences of SARS-CoV-2, and a total of 15 sequences of variant D614G of 170 reference sequences of SARS-CoV-2 were found, which was also confirmed by (KORBER et al., 2020). The 'GBPD060' vaccine induced a high level of specific antibodies with a single immunization, which covers the entire length of the protein peak, suggesting that a mixture of highly relevant antibodies against these domains were developed (NAG et al., 2021).

According to Huang et al. (2021), a vaccine against SARS-CoV-2 of the mRNA type that encodes RBD, formulated in liposomes, was developed and investigated the influence of administration routes on immunogenicity. The vaccine expressed the receptor-binding domain (RBD) 'in vivo' and successfully induced specific antibodies against SARS-CoV-2 in the vaccinated mice, efficiently neutralizing the virus. According to the author, the typical morphology of liposomes was analyzed using TEM, showing nearly spherical particles in size of about $50-150 \mathrm{~nm}$. The immunological tolerance of the LPX/RBD-mRNA vaccine was tested in mice inoculated through five different injection routes (iv-intravenous, im-intramuscular, ih-hypodermic, id-intradermal, ip-intraperitoneal) with $30 \mu \mathrm{g}$ of RBD-mRNA. Alterations in eotaxin, GRO- $\alpha$, IP-10, RANTES, and MCP-1 were found after 12 hours of administration and all these groups showed an increase in these indices of immune function. After the booster vaccination, all mice were sacrificed and the main organs were excised and examined, the 
results showed that there was no obvious histopathological difference in the main organs of the control and treatment groups, demonstrating that the LPX/RBR-mRNA vaccine did not cause systemic toxicity (HUANG et al., 2021).

According to Chiba et al. (2021), developed a vaccine based on a platform (VLPs) coated with the bacteriophage protein MS2 (single-stranded RNA icosahedral virus), generating nanoparticles containing multiple copies of the spike protein (S) of SARS-CoV-2. The use of these nanoparticles as vaccines generated high neutralizing and animal antibody responses against SARS-CoV-2. Nanoparticles such as pseudo viral particles (VLPs), but not infectious, are ideal structures for antigen display because they emulate or mimic many of the properties of natural viruses (SHIN et al., 2020). Chiba et al. (2021), generated a VLP structure coated with the protein streptavidin (SA) that exhibits biotinylated (molecularly bound) antigens, such as the biotinylated SARS-CoV-2 protein (S), based on the very high affinity of the biotin-streptavidin interaction. The vaccine proved to be highly effective, protecting hamsters against SARS-CoV-2 after a single immunization, and the platform can be adapted to variant strains.

Karpenko et al. (2021), developed an mRNA-RBD vaccine that encodes the receptor-binding domain (RBD) of the protein 'S' of SARS-CoV-2. The vaccine uses a polycationic polyglucin conjugate with spermidine for mRNA delivery. She demonstrated increased production of antibodies with virus-neutralizing activity in mice. The use of mRNA for virus vaccines has become increasingly popular, as they present attractive features, for example, design simplicity, low production cost, low reactogenicity (adverse reaction) (PARDI et al., 2018; KARPENKO et al., 2021). Some ways found by researchers to increase the immune response to an mRNA vaccine is to encapsulate it in nanoparticles, using biocompatible and biodegradable materials, protecting them from degradation, and facilitating absorption by antigen-presenting cells (JASDAVE et al., 2017; KARPENKO et al., 2021). According to Karpenko et al. (2021), the choice of a cationic polymer polyglycine: spermidine conjugate (PGS - Polyglycin spermidine conjugate) is because it has been previously successful in works for the delivery of DNA vaccines (KARPENKO et al., 2020). The average size of monodisperse hydrodynamic particles was between 164 and $20 \mathrm{~nm}$, confirmed by electron microscopy.

Teijaro and Farber (2021), explained the significant progress in cutting-edge vaccine technology over the last decade, with the approval of two types of vaccines against SARS-CoV-2 for emergency use. Approved vaccines developed by Pfizer-BNT162b2 and Moderna-mRNA-1273 employ mRNA technology and a lipid nanoparticle (LNP) delivery system, while AstraZeneca approved formulations (ChAdox1-s-(AZD122)), Johnson \& Johnson-Ad26.COV2.S, and Gam-COVID-vac (rAd26-s+rAd5-8) (Sputnik V) are delivered in a non-replicating recombinant adenovirus DNA vector system (POLACK et al., 2020; BADEN et al., 2021). According to Baden et al. (2021), mRNA and adenovirus vaccines compile the production of the protein (S) of SARS-CoV-2, which is the fundamental point for the production of neutralizing antibodies caused by natural infections and therapeutic monoclonal antibodies. 
According to Tsiambas et al. (2021), the study demonstrated that intradermal/muscular injection of BNT162b2 and mRNA-1273 vaccines demonstrated a longer duration of mRNA compared to intravenous injection. The mRNA vaccine platform includes specific mRNA parts to encode the entire trimeric form of the protein $(\mathrm{S})$ and the corresponding RBD region in the case of the BNT162b2 vaccine (Pfizer), or stable Spike protein in the mRNA-1273 vaccine. Regarding the intracellular action structure, the mRNA platform neither interacts with the host cell's DNA nor modifies the cell's DNA, because it is generally not integrated into it.

Table 2 shows data from clinical trials (available) of some vaccines used in the study, according to the screening platform and vaccine overview of the World Health Organization (WHO, 2021). The SARS-CoV-2 virus is evolving, with mutations in the receptor-binding domain (RBD) of particular concern. It is important to know how much cross-protection is offered between strains after vaccination or infection (BECKER et al., 2021).

Table 2 - Clinical trial data of some vaccines used in the study, described by the World Health Organization.

\begin{tabular}{|c|c|c|c|c|c|c|}
\hline Developers & Name of vaccine & Phase I & Phase II & Phase III & Phase IV & Number of doses \\
\hline Academy of Military Science & & & & & & 2 \\
\hline (AMS), Walvax Biotechnology & ARCov & & & $\mathrm{X}$ & & Day $0+14$ or \\
\hline and Suzhou Abogen Biosciences & & & & & & Day $0+28$ \\
\hline \multirow{2}{*}{ Pfizer/BioNtech + Fosun Pharma } & \multirow{2}{*}{ BNT162b2 } & & & & \multirow{2}{*}{$X$} & 2 \\
\hline & & & & & & Day $0+21$ \\
\hline \multirow{2}{*}{ CureVac AG } & \multirow{2}{*}{$\mathrm{CVnCoV}$} & & & \multirow{2}{*}{$X$} & & 2 \\
\hline & & & & & & Day $0+28$ \\
\hline \multirow{2}{*}{ Novavax } & \multirow{2}{*}{ NVX-CoV2373 } & & & \multirow{2}{*}{$\mathrm{X}$} & & 2 \\
\hline & & & & & & Day $0+21$ \\
\hline \multirow{2}{*}{ Moderna } & \multirow{2}{*}{$m R N A-1273$} & & & & \multirow{2}{*}{$\mathrm{X}$} & 2 \\
\hline & & & & & & Day0+28 \\
\hline
\end{tabular}

Source: Author construction.

\section{CONCLUSION}

Different ways of using nanotechnology to create vaccines were analyzed in this work, specifically against SARS-CoV-2. Efficiency in virus neutralization was observed in all analyzed references. Some used lipid nanoparticles loaded with messenger RNA (mRNA), which have been widely used nowadays to prevent viral infections with several advantages, for example, fast manufacturing speed, potent immunogenicity, and good safety profile. Other vaccines used VLP technology and proved to be strongly immunogenic in animal tests, inducing large amounts of neutralizing antibody responses against wild-type SARS-CoV-2.

The main objective of this work was to show that nanotechnology presents a platform for vaccines development against pandemics, which need a profile of mass creation in a short period and present safety and efficiency. All results were encouraging and bring hope to the use of nanotechnology in vaccines, specifically against corona viruses. 


\section{REFERENCES}

BADEN, L. R. et al. Efficacy and safety of the mRNA-1273 SARS-CoV-2 vaccine. The New England Journal of Medicine. 384:403-416, 2021. DOI: 10.1056/NEJMoa2035389.

BECK, D. J. et al. mRNA therapeutics in cancer immunotherapy. Molecular Cancer, n. 69, 2021. DOI: 10.1186/s12943-021-01348-0.

BECKER, M. et al. Immune response to SARS-CoV-2 variants of concern in vaccinated individuals. Nature communications, 12(1): 3109, 2021. DOI:10.1038/s41467-021-23473-6.

BROUWER, P. J. M. et al. Two-component spike nanoparticle vaccine protects macaques from SARS-CoV-2 infection. Cell, 184, p. 1188-1200, 2021. DOI:10.1016/j.cell.2021.01.035.

CHANDLER, M. et al. Innate immune responses triggered by nucleic acids inspire the design of immunomodulatory nucleic acid nanoparticles (NANPs). Current Opinion Biotechnology 63, 2020. DOI:10.1016/j.copbio.2019.10.011.

CHIBA, S. et al. Multivalent nanoparticle-based vaccines protect hamsters against SARS-CoV-2 after a single immunization. Communications Biology, v. 4, 2021. DOI: 10.1038/s42003-021-02128-8.

DONG, E; DU, H; GARDNER, L. An interactive web-based dashboard to track COVID-19 in real time. The Lancet Infectious Diseases. Dis. 20, 533-534, 2020. DOI:10.1016/S1473-3099(20)30120-1.

FERRAZ, W. G. L. Vacinas a base de subunidade proteica para prevenção da covid-19: mecanismos de ação, ensaios clínicos e pedidos de patentes. Ministério da Economia, Instituto Nacional da Propriedade Industrial, Observatório de Tecnologias Associadas a Covid-19, 2021. Available in: https://bit.ly/3qo9BD2.

HOECKE, V. L. et al. mRNA in cancer immunotherapy: beyond a source of antigen. Molecular Cancer, n. 48, 2021. DOI: 10.1186/s12943-021-01329-3.

HOFFMANN, D. et al. CVnCoV and CV2CoVprotect human ACE2 transgenic mice from ancestral B BavPat1 and emerging B.1.351 SARS-CoV-2. Nature Communications, n. 4048, 2021. DOI: 10.1038/s41467-021-24339-7. 
HOFFMANN, M. et al. SARS-CoV-2 Cell Entry Depends on ACE2 and TMPRSS2 and Is Blocked by a Clinically Proven Protease Inhibitor. Cell, p. 271-280, 2020. DOI: 10.1016/j.cell.2020.02.052.

HOPKINS. Johns Hopkins University Medicine. Coronavirus Resource Center, 2021. Available in: https://coronavirus.jhu.edu.

HUANG, H. et al. The investigation of mRNA vaccines formulated in liposomes administrated in multiple routes against SARS-CoV-2. Journal of Controlled Release, v. 355, p. 449-456, 2021. DOI: $10.1016 /$ j.jconrel.2021.05.024.

JAHANAFROOZ, Z. et al. Comparison of DNA and mRNA vaccines against cancer. Drug Discovery Today, 2019. DOI: 10.1016/j.drudis.2019.12.003.

JASDAVE, S. C. et al. An RNA nanoparticle vaccine against Zika virus elicits antibody and CD8+ T cell responses in a mouse model. Nature Scientific Reports, 2017. DOI: 10.1038/s41598-017-00193-w.

JIANG, H. T. et al. SARS-CoV-2 spike glycoprotein vaccine candidate NVX-CoV2373 immunogenicity in baboons and protection in mice. Nature Communications, v. 12, 2021. DOI: 10.1038/ s41467-020-20653-8.

KARPENKO, I. L. et al. Cationic Polymers for the Delivery of the Ebola DNA Vaccine Encoding Artificial T-Cell Immunogen. Vaccines (Basel), 2020. DOI: 10.3390/vaccines8040718.

KARPENKO, I. L. et al. Delivery of mRNA Vaccine against SARS-CoV-2 Using a Polyglucin: Spermidine Conjugate. Vaccines, 2021. DOI: 10.3390/vaccines9020076.

KORBER, B. et al. Tracking Changes in SARS-CoV-2 Spike: Evidence that D614G increases Infectivity of the COVID-19 Virus, Cell, v. 182, p.812-827, 2020. DOI: 10.1016/ j.cell.2020.06.043.

LARSEN, E. S. et al. Subunit vaccine protects against a clinical isolate of Mycobacterium avium in wild type and immunocompromised mouse models. Nature Scientific Reports, n. 9040, 2021. DOI: 10.1038/s41598-021-88291-8.

LASRADO, N. et al. Attenuated strain of CVB3 with a mutation in the CAR-interacting region protects against both myocarditis and pancreatitis. Nature Scientific Reports, n. 12432, 2021. DOI: 10.1038/s41598-021-90434-w. 
MAINARDES, M. R; DIEDRICH, C. The potential role of nanomedicine on COVID-19 therapeutics. Therapeutic. Delivery, 2020. DOI: 10.4155/tde-2020-0069.

MAO, L; CHEN, Z; WANG, Y; CHEN, C. Design and application of nanoparticles as vaccine adjuvants against human corona virus infection. Journal of Inorganic Biochemistry, 219, 111454, 2021. DOI: 10.1016/j.jinorgbio.2021.111454.

NAG, K. et al. An mRNA-based vaccine candidate against SARS-CoV-2 elicits stable immune-response with single dose. Vaccine, v. 39, p. 3745-3755, 2021. DOI: 10.1016/j.vaccine.2021.05.035.

PACHECO, A. J. T; SILVA, M. F; SOUZA, G. D; SILVA, M. C. V; FARIA, S. R. Coronavirus disease 2019 (COVID-19): Updated evidence of comparative overview, diagnosis and treatments. Revista Cereus, v. 12, n. 3, p. 228-243, 2020. Available in: https://bit.ly/3Hy3Tph.

PARDI, N; HOGAN, M. J; PORTER, F. W; WEISSMAN, D. mRNA vaccines - a new era in vaccinology. Nature Reviews Drug Discovery, 17, 261-279, 2018. DOI: 10.1038/nrd.2017.243.

PARK, K. S. et al. Lipid-based vaccine nanoparticles for induction of humoral immune responses against HIV-1 and SARS-CoV-2. Journal of Controlled Release, 330, 529-539, 2021. DOI: 10.1016/j.jconrel.2020.12.031.

PASHINE, A; VALIANTE, N. M; ULMER, J. B. Targeting the innate immune response with improved vaccine adjuvants. Nature Medicine, 11, S63-S68, 2005. DOI: 10.1038/nm1210.

POLACK, F. P. et al. Safety and efficacy of the BNT162b2 mRNA Covid-19 vaccine. The New England Journal of Medicine, 383:2603-2615, 2020. DOI: 10.1056/NEJMoa2034577.

RAUCH, S. et al. mRNA-based SARS-CoV-2 vaccine candidate CVnCoV induces high levels of virus-neutralising antibodies and mediates protection in rodents. Npj Vaccines, v. 6, 2021. DOI: 10.1038/s41541-021-00311-w.

SAHIN, U. et al. BNT162B2 Vaccine induces neutralizing antibodies and poly-specific $\mathrm{T}$ cells in humans. Nature, 2021. DOI: 10.1038/s41586-021-03653-6.

SHI, S. et al. Vaccine adjuvants: Understanding the structure and mechanism of adjuvanticity. Vaccine, 37, 3167-3178, 2019. DOI: 10.1016/j.vaccine.2019.04.055. 
SHIN, D. M. et al. COVID-19 vaccine development and a potencial nanomaterial path forward. Nature Nanotechnology, 15, p. 646-655, 2020. DOI: 10.1038/s41565-020-0737-y.

SINGH, K; MEHTA, S. The clinical development process for a novel preventive vaccine: An overview. Postgraduate Medical Journal, 62, 4, 2016. DOI: 10.4103/0022-3859.173187.

TAN, K. T. et al. A COVID-19 vaccine candidate using SpyCatcher multimerization of the SARS-CoV-2 spike protein receptor-binding domain induces potent neutralising antibody responses. Nature Communications, 2021. DOI: 10.1038/s41467-020-20654-7.

TEIJARO, R. J; FARBER L. D. COVID-19 vaccines: modes of immune activation and future challenges. Nature Reviews Immunology, 21(4): 195-197, 2021. DOI: 10.1038/s41577-021-00526-x.

TICHA, O; KLEMM, D; MOOS, L; BEKEREDJIAN-DING, I. A cell-based in vitro assay for testing of immunological integrity of Tetanus toxoid vaccine antigen. Npj Vaccines, 6, 88, 2021. DOI:10.1038/s41541-021-00344-1.

TSIAMBAS, E. et al. Impact of Ribosome Activity on SARS-CoV-2 LNP - Based mRNA Vaccines. Frontiers in Molecular Biosciences, 2021. DOI: 10.3389/fmolb.2021.654866.

WANG, Y. et al. mRNA vaccine: a potencial therapeutic strategy. Molecular Cancer, v. 20, 2021. DOI: 10.1186/s12943-021-01311-z.

WEISS, C. et al. Toward nanotechnology-enabled approaches against the COVID-19 pandemic. ACS Nano, 14, 6383-6406, 2020. DOI: 10.1021/acsnano.0c03697.

WHO. World Health Organization. COVID-19 vaccine tracker and landscape, 2021. Available in: https://bit.ly/3z4FowE.

ZHANG, N. et al. A Thermostable mRNA Vaccine against COVID-19. Cell, v. 182, p. 1271-1283, 2020. DOI: 10.1016/j.cell.2020.07.024, 2020.

ZHU, Z. et al. The psychological status of people affected by the COVID-19 outbreak in China. Journal of Psychiatric Research, 129, 1-7, 2020. DOI: 10.1016/j. jpsychires.2020.05.026. 